\title{
Exogenous melatonin in the treatment of pain: a systematic review and meta-analysis
}

\author{
Chaojuan Zhu' ${ }^{1,2, *}$, Yunyun Xu ${ }^{1, *}$, Yonghong Duan ${ }^{1, *}$, Wei Li ${ }^{3}$, Li Zhang ${ }^{1}$, Yang Huang ${ }^{1}$, \\ Wei Zhao ${ }^{1}$, Yutong Wang ${ }^{1}$, Junjie Li ${ }^{1}$, Ting Feng ${ }^{1}$, Xiaomei $\mathrm{Li}^{4}$, Xuehui Hu${ }^{2,5}$ and \\ Wen Yin ${ }^{1}$ \\ ${ }^{1}$ Department of Emergency Medicine, Xijing Hospital, The Fourth Military Medical University, Xi'an 710032, China \\ ${ }^{2}$ Department of Nursing, Xijing Hospital, The Fourth Military Medical University, Xi'an 710032, China \\ ${ }^{3}$ Department of Human Anatomy, Histology and Embryology, The Fourth Military Medical University, Xi'an 710032, China \\ ${ }^{4}$ Faculty of Nursing, College of Medicine, Xi'an Jiaotong University, Xi'an 710049, China \\ ${ }^{5}$ Department of Dermatology, Xijing Hospital, The Fourth Military Medical University, Xi'an 710032, China \\ *These authors contributed equally to this work
}

Correspondence to: Wen Yin, email: yinwenxijing@163.com

Xuehui Hu, email: huxuehuixijing@163.com

Keywords: melatonin, pain, brain-derived neurotrophic factor, meta-analysis

Received: August 09, $2017 \quad$ Accepted: September 20, $2017 \quad$ Published: October 05, 2017

Copyright: Zhu et al. This is an open-access article distributed under the terms of the Creative Commons Attribution License 3.0 (CC BY $3.0)$, which permits unrestricted use, distribution, and reproduction in any medium, provided the original author and source are credited.

\section{ABSTRACT}

Melatonin is an important hormone for regulating mammalian circadian biology and cellular homeostasis. Recent evidence has shown that melatonin exerts anti-nociception effects in both animals and humans. However, according to clinical trials, the antinociception effects of melatonin are still controversial. The aim of this meta-analysis was to investigate the anti-nociception effects of melatonin premedication. The primary outcome was the effects of melatonin on pain intensity. The secondary outcomes included the number of patients with analgesic requirements, total analgesic consumption, and brain-derived neurotrophic factor (BDNF) levels. In total, 19 studies were included in the current meta-analysis. The pooling data show that melatonin significantly decreased the pain intensity, as evidenced by the pain scores. Moreover, melatonin administration also reduced the proportion of patients with analgesic requirements and BDNF levels. However, the effects of melatonin on total analgesic consumption still require further confirmation. Collectively, the current meta-analysis supports the use of melatonin for anti-nociception.

\section{INTRODUCTION}

As an important hormone, melatonin is an accepted antioxidant and anti-inflammatory agent [1-8]. Melatonin is reported to regulate circadian biology, cellular autophagy and endoplasmic reticulum homeostasis [9-11]. Moreover, its protective roles against obesity, diabetes, sepsis and fibrosis have been widely observed [11-15]. In particular, its administration significantly improved sleep quality, anxiety, and depression [16-18]. Furthermore, melatonin receptors have been identified in the spinal cord tissue $[19,20]$. Thus, melatonin may exert anti-nociception effects.

Interestingly, pain perception, especially heat and cold pain tolerance, is observed to vary diurnally, which may result from variations in melatonin levels [21]. In particular, acute pain stimuli influence the salivary melatonin levels [22]. Reduced endogenous melatonin exacerbates nerve injury-induced neuropathic pain [23], whereas melatonin administration significantly attenuates sleep deprivation-induced neuropathic pain [24]. Recent experimental evidence has also shown that melatonin could significantly alleviate pain behaviors under other conditions [19, 25-27].

Melatonin does not exhibit toxicity at the doses used [28]; even high-dose intravenous melatonin $(100 \mathrm{mg})$ does not induce significant adverse effects [29-32]. Although some clinical trials have reported the anti-nociception effects of melatonin [33-45], several other studies have shown that melatonin has no significant effects on pain $[16,30,46,47]$. To determine whether exogenous melatonin exerts anti-nociception effects in the human population, we conducted this meta-analysis. 


\section{MATERIALS AND METHODS}

\section{Data sources and searches}

Two authors (Chaojuan Zhu and Yonghong Duan) independently searched the electronic databases, including MEDLINE (1990 to July 2017), EMBASE (1990 to July 2017), Scopus (1988 to July 2017), PsycINFO (1990 to July 2017), and the Cochrane Library (Issue 5 of 12, July 2017). Searches were limited to humans but were not limited by published language and publication type. References of published original articles, reviews and contacted experts were further searched. Melatonin, $\mathrm{N}$-acetyl-5-methoxy tryptamine, pain, ache, dolor, pain management and analgesia were used as search terms. [((((pain) OR ache) OR dolor) OR pain management) and ((melatonin) OR N-acetyl-5-methoxy tryptamine)] were used as search phrases. The full study flow diagram is shown in Figure 1.

RCTs enrolled participants with any type of pain, including inflammatory pain, operation-associated pain, experimental pain and procedural pain. Melatonin could be administered orally or intravenously, either solely or in combination with other drugs. Both trials comparing melatonin with placebo or with positive control were included. Trial protocols without results, animal experiments, and studies without control groups were excluded.

\section{Data extraction}

Two authors (Chaojuan Zhu and Xu Yunyun) independently extracted data, including study characteristics and the main outcomes. When discrepancies appeared, consensus was achieved through discussion with a third author (Yonghong Duan). Characteristics of patients, such as age, condition, number of patients and intervention, were collected.

The primary outcome was pain intensity, as evidenced by pain scores. Based on the results reported in RCTs, the Visual Analog Scale (VAS) was the most used scale in the included trials. Additionally, children's anxiety and pain scales and premature infant pain profiles were also pooled. Secondary outcomes were the number of patients with analgesic requirements, total analgesic consumption, and brain-derived neurotrophic factor (BDNF) levels.

When only standard error (SE) was reported, SE was transformed to standard deviation (SD) using the formula: $\mathrm{SD}=\mathrm{SE} \times \sqrt{\mathrm{n}}$. When the $95 \%$ confidence interval $(95 \% \mathrm{CI})$ was recorded, $\mathrm{SD}=\sqrt{\mathrm{n}} \times($ upper limit-lower limit $) / 3.92$. When only the median and interquartile range (IQR) were recorded, they were used to estimate the mean and SD: mean $\approx$ median, $\mathrm{SD} \approx$ Norm $\mathrm{IQR}=(\mathrm{P} 75-\mathrm{P} 25) \times 0.7413$ according to the Cochrane Handbook for Systematic Reviews of Interventions [48]. If the mentioned data were unavailable in

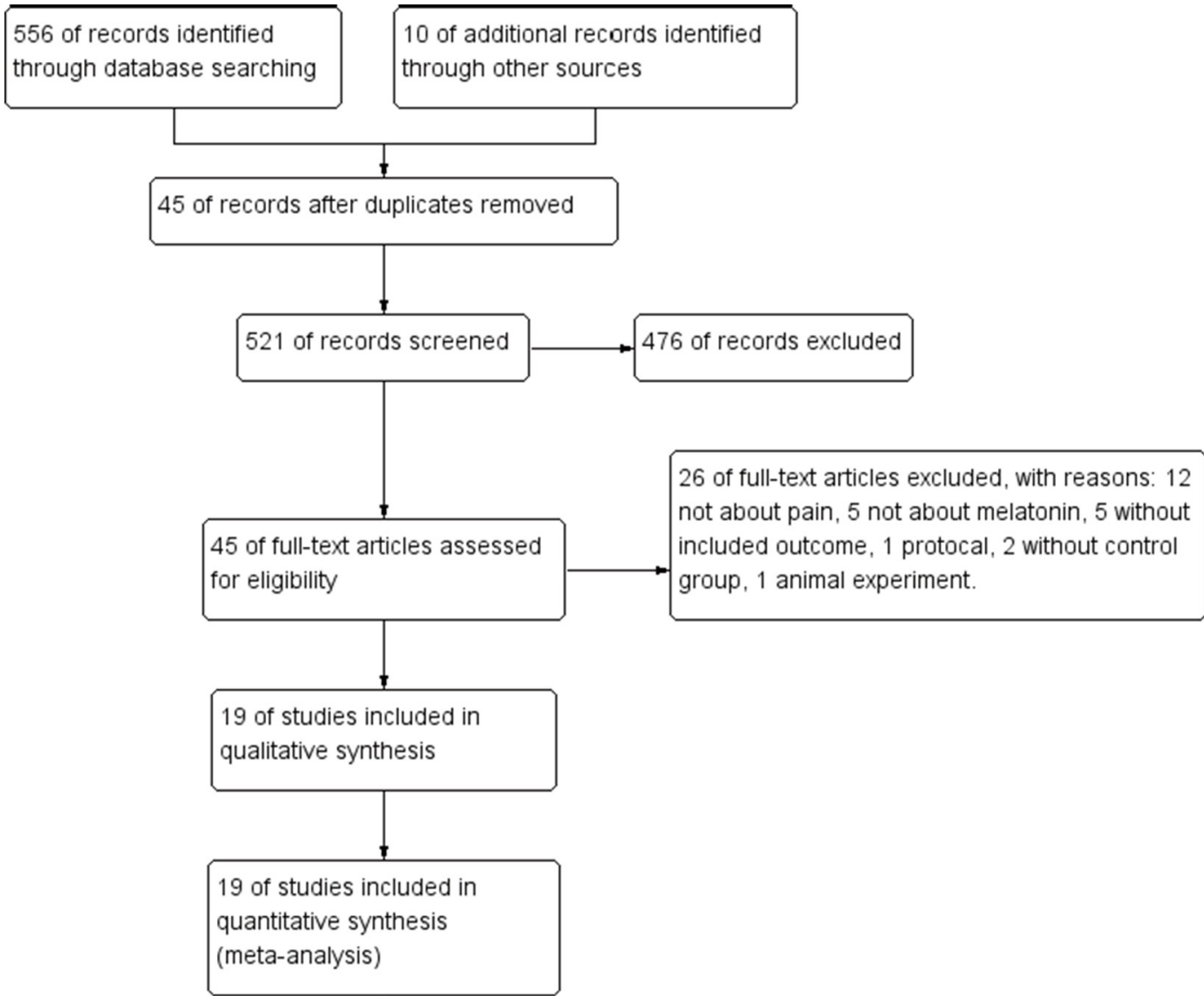

Figure 1: Study flow diagram. VAS, Visual Analog Scale. 
the text, we attempted to contact the corresponding authors to obtain the related information. If the present data in the figures were not available in the text and it was impossible to retrieve them from the corresponding authors, ImageJ (National Institutes of Health, Bethesda, MD) was applied to measure the values in the figures.

\section{Quality assessment}

Two authors (Chaojuan Zhu and $\mathrm{Xu}$ Yunyun) independently assessed the quality of the included trials according to the Jadad scales (5 items) [49]. Randomization, blinding, and withdrawals and dropouts were assessed. Table 1 presents the assessments of all included studies. The quality of the trial was described as high (score 5), moderate (score 4), or low (scores 1-3). The trials with low quality were not relied upon in the data pooling. Cohen's kappa $(\kappa)$ was utilized to measure the inter-rater agreement.

\section{Statistical analysis}

Review Manager analysis software (RevMan 5.2) was used to analyze the collected data according to the Cochrane Handbook for Systematic Reviews of Interventions [48]. For continuous data measured by different scales, we used weighted mean differences (WMDs) with applicable 95\% CIs to measure the mean values or mean changes. WMDs were calculated for pain intensity, total analgesic consumption and BDNF levels. For dichotomous data, the odds ratios (ORs) with applicable $95 \%$ CIs were used for the pooling data. ORs were calculated for the number of patients with analgesic requirements.

$\mathrm{I}^{2}$ statistics were used to measure heterogeneity of the RCTs. If the $\mathrm{I}^{2}$ value was less than $50 \%$, a fixed-effects model was applied. If the $\mathrm{I}^{2}$ value was $50 \%$ or more, a subgroup analysis was conducted. Subgroup analyses for pain intensity primarily included different pain types and compared groups, while analyses for total analgesic consumption included the stage used and compared groups. If a significant heterogeneity could not be identified by subgroup analysis, a random-effects model meta-analysis was used [48]. Sensitivity analyses were conducted to examine the stability of the pooling outcome and to trace the heterogeneity source by excluding the sole study with low quality or high risk of bias. Publication bias was tested using a funnel plot (Figure 2) and Egger's test [50, 51].

\section{RESULTS}

Figure 1 present the full study screening process. Ultimately, 19 studies were included in this meta-analysis. Their quality assessment is shown in Table 1. High interrater reliability of initial decisions on the inclusion of studies was indicated $(\kappa=0.838,95 \% \mathrm{CI}: 0.53-1)$. All of the included studies were RCTs. Among them, 18 studies were randomized double-blind trials, 14 studies were placebo-controlled trials, and 17 studies were assessed as high quality. In total, 586 patients were included in the melatonin groups, while 507 patients received control therapy, including placebo and standard therapy. The characteristics of these studies are summarized in Table 2.

Pain intensity indicated by pain scores was the primary outcome in this meta-analysis. This outcome has been reported in 18 studies. Figure 3 showed the significantly strong efficacy of melatonin over the control on the anti-nociception effect (WMD $=-2.43$, 95\% CI, -2.5 to $-2.36 ; P<0.00001)$ with significant statistical heterogeneity $\left(\mathrm{I}^{2}=98 \%\right)$. A subgroup analysis was conducted: compared with placebo, melatonin administration significantly decreased the scores of operation-associated pain under topical anesthesia $(\mathrm{WMD}=-0.86,95 \% \mathrm{CI},-1.33$ to $-0.39 ; P=0.0004$; $\mathrm{I}^{2}=27 \%$ ), operation-associated pain under general anesthesia $(\mathrm{WMD}=-2.15,95 \% \mathrm{CI},-2.24$ to -2.06 ; $\left.P<0.00001 ; \mathrm{I}^{2}=0 \%\right)$, inflammatory pain (WMD $=$ $-1.62,95 \% \mathrm{CI},-1.79$ to $\left.-1.46 ; P<0.00001 ; \mathrm{I}^{2}=45 \%\right)$, procedural pain $(\mathrm{WMD}=-4.79,95 \% \mathrm{CI},-5.15$ to -4.79; $\left.P<0.00001 ; \mathrm{I}^{2}=99 \%\right)$, and experimental pain $\left(\mathrm{WMD}=-1.23,95 \% \mathrm{CI},-1.89\right.$ to $-0.57 ; P=0.0003 ; \mathrm{I}^{2}$ $=0 \%$ ). Significant heterogeneity for included subgroup differences was indicated $\left(\mathrm{I}^{2}=99.5 \%, P<0.00001\right)$. Among all of the subgroups, no statistical heterogeneity was indicated except for the procedural pain group. As shown in Table 2, the procedural pain group included pain under blood withdrawal, endotracheal intubation and intravenous cannula placement. Although significant anti-nociception effects of melatonin were shown in every study, the beneficial scales of melatonin were different among these procedural operations. Further subgroup analysis requires more trials. Additionally, melatonin was comparable to the positive control (WMD $=-0.53$, $95 \% \mathrm{CI},-1.26$ to $0.21 ; P=0.16 ; \mathrm{I}^{2}=34 \%$ ). Sensitive analysis showed that no study significantly influenced the reliability of the pooled results.

The secondary outcomes were the number of patients with analgesic requirements (Figure 4), total analgesic consumption (Figure 5), and BDNF levels (Figure 6). As reported in 4 studies, melatonin administration significantly decreased the proportion of patients requiring analgesic drugs $(\mathrm{OR}=0.43,95 \% \mathrm{CI}$, 0.24 to $0.79 ; P=0.006 ; \mathrm{I}^{2}=0 \%$ ) (Figure 4 ). A randomeffects model was used to evaluate the effects of melatonin on requirements with analgesic drugs (Figure 5). Pooling data from 10 studies revealed significantly fewer patients with analgesic requirements in the melatonin group (Random model, WMD $=-2.69,95 \%$ CI, -4.07 to -1.86 ; $P<0.00001 ; \mathrm{I}^{2}=99 \%$ ). Further subgroup analysis showed that melatonin significantly reduced the postoperative usage of analgesic drugs (Random model, WMD $=-11.27$, $95 \% \mathrm{CI},-13.82$ to $-8.72 ; P<0.00001 ; \mathrm{I}^{2}=100 \%$ ), while 
Table 1: Jadad scales of the included studies

\begin{tabular}{lcccc}
\hline \multicolumn{1}{c}{ References } & Randomisation & Double blind & Withdrawals and dropouts & Total \\
\hline Gitto 2016 [33] & 2 & 2 & 1 & 5 \\
Kirksey 2015 [46] & 2 & 2 & 1 & 5 \\
Marseglia 2015 [67] & 2 & 2 & 1 & 5 \\
Seet 2015 [47] & 2 & 2 & 1 & 5 \\
Andersen 2015 [30] & 2 & 2 & 1 & 5 \\
de Zanette 2014 [34] & 2 & 2 & 1 & 5 \\
Khezri 2013 [35] & 2 & 2 & 1 & 5 \\
Vidor 2013 [68] & 2 & 2 & 1 & 5 \\
Khezri 2013a [37] & 2 & 2 & 1 & 5 \\
Schwertner 2013 [38] & 2 & 2 & 1 & 5 \\
Stefani 2013 [36] & 2 & 2 & 1 & 5 \\
Gitto 2012 [39] & 1 & 1 & 2 \\
Hussain 2011 [40] & 1 & 1 & 1 & 3 \\
Borazan 2010 [41] & 2 & 2 & 1 & 5 \\
Ismail 2009 [42] & 2 & 2 & 1 & 5 \\
Caumo 2009 [44] & 2 & 2 & 1 & 5 \\
Mowafi 2008 [43] & 2 & 2 & 1 & 5 \\
Caumo 2007 [45] & 2 & 2 & 1 & 5 \\
Song 2005 [57] & 1 & 2 & 1 & 4 \\
\hline
\end{tabular}

no significant reductions were observed in operative usage (Random model, $\mathrm{WMD}=-24.55,95 \% \mathrm{CI},-49.91$ to 0.81 ; $P=0.06 ; \mathrm{I}^{2}=93 \%$ ) and non-operative usage (Random model, $\mathrm{WMD}=-0.25,95 \% \mathrm{CI},-0.56$ to $0.07 ; P=0.12$; $\left.\mathrm{I}^{2}=0 \%\right)$. However, melatonin was comparable to the positive control (Random model, $\mathrm{WMD}=-1.23,95 \% \mathrm{CI}$, -3.50 to $\left.1.04 ; P=0.29 ; \mathrm{I}^{2}=90 \%\right)$. Sensitivity analysis found that after exclusion of results from Borazan et al in the postoperative group, the overall effects (Random model, $\mathrm{WMD}=-0.17,95 \% \mathrm{CI},-3.50$ to $1.04 ; P=0.26$; $\mathrm{I}^{2}=86 \%$ ) and effects in postoperative usage (Random model, $\mathrm{WMD}=-0.10,95 \% \mathrm{CI},-0.27$ to $0.07 ; P=0.23 ; \mathrm{I}^{2}$ $=65 \%$ ) became insignificant. Furthermore, melatonin also significantly downregulated $\mathrm{BDNF}$ levels $(\mathrm{WMD}=-5.43$, $95 \%$ CI, -22.45 to $-1.23 ; P=0.001 ; \mathrm{I}^{2}=0 \%$ ) (Figure 6 ).

The funnel plot is shown in Figure 2. No significant publication bias was observed (Eggers test: 1.121428, 95\% CI: -3.588125 to $5.830981, P=0.623)$. No further trials were identified through extensive searches. No significant adverse events were reported in the included studies. Because the safety of exogenous melatonin supplementation has been confirmed, we did not pool the data relevant to this outcome.

\section{DISCUSSION}

This pooling study showed that melatonin could significantly decrease the intensity of every type of pain, including operation-associated pain under topical anesthesia, operation-associated pain under general anesthesia, inflammatory pain, procedural pain, and experimental pain. The mechanism for this reduction may depend on decreasing BDNF levels. Furthermore, melatonin also decreased the proportion of patients requiring additional analgesic drugs, but its effects on total analgesic consumption still require further confirmation.

In the excluded studies, the analgesic effects of melatonin were also demonstrated. In critically ill patients, long-term administration of melatonin also significantly improved the patients' pain [52]. Two other studies showed that melatonin significantly reduced the frequency and intensity of nocturnal pain in patients with ulcer-like dyspepsia [53] and the intensity of visceral pain in patients with irritable bowel syndrome [54]. Another trial was designed to investigate the efficacy of melatonin in Intensive Care Unit patients [55]. Accompanying the alleviation of pain, melatonin also significantly improved sedation and anxiety [35, 37, 42, 43]. Similarly, compared with midazolam, melatonin also significantly contributed to sedation induction in children [31]. These studies were excluded primarily due to their unavailable data about the included outcomes, especially the pain scores.

The diurnal variation of pain tolerance may be attributed to melatonin variation [21]. Further evidence has shown that endogenous elevation of melatonin also improves pain tolerance. Probiotic administration increased the rectal distension pain threshold in irritable bowel 
Table 2: Study characteristics

\begin{tabular}{|c|c|c|c|c|c|c|c|c|}
\hline & References & Population & Condition & Experiment group & Numbers & Control groups & Numbers & Administration \\
\hline \multirow[t]{11}{*}{$\begin{array}{l}\text { Operation- } \\
\text { associated } \\
\text { pain }\end{array}$} & $\begin{array}{l}\text { Gitto } 2016 \\
\text { [33] }\end{array}$ & Children aged 5 to 14 & Elective surgery & $\begin{array}{l}\text { Melatonin } 0.5 \mathrm{mg} / \mathrm{kg} \\
(\max 20 \mathrm{mg})\end{array}$ & 46 & Midazolam $0.5 \mathrm{mg} / \mathrm{kg}$ & 46 & $\begin{array}{l}\text { Oral premedication } 40 \\
\text { min before anaesthesia }\end{array}$ \\
\hline & $\begin{array}{l}\text { Kirksey } \\
2015[46]\end{array}$ & $\begin{array}{l}\text { ASA I-III patients } \\
\text { aged } 18 \text { to } 90\end{array}$ & $\begin{array}{l}\text { Total knee arthroplasty under } \\
\text { regional anesthesia }\end{array}$ & Melatonin $5 \mathrm{mg}$ & 19 & Placebo & 18 & $\begin{array}{l}\text { Oral premedication at the } \\
\text { bedtime starting on the third } \\
\text { preoperative night and continuing } \\
\text { throughout the third postoperative } \\
\text { night }\end{array}$ \\
\hline & $\begin{array}{l}\text { Seet } 2015 \\
{[47]}\end{array}$ & $\begin{array}{l}\text { ASA I-II patients aged } \\
21 \text { to } 65\end{array}$ & $\begin{array}{l}\text { Elective extraction of all four } \\
\text { wisdom teeth under general } \\
\text { anaesthesia }\end{array}$ & Melatonin $6 \mathrm{mg}$ & 36 & Placebo & 37 & $\begin{array}{l}\text { Oral premedication } \\
90 \text { min before surgery }\end{array}$ \\
\hline & $\begin{array}{l}\text { Khezri } \\
2013 \text { [35] }\end{array}$ & $\begin{array}{l}\text { ASA I-III patients } \\
\text { aged } 25 \text { to } 80\end{array}$ & $\begin{array}{l}\text { Elective cataract surgery with } \\
\text { intraocular lens implantation } \\
\text { using phacoemulsification } \\
\text { under topical anesthesia for } \\
\text { the first time }\end{array}$ & Melatonin $3 \mathrm{mg}$ & 30 & Placebo & 30 & $\begin{array}{l}\text { Sublingual premedication } \\
60 \text { min before surgery }\end{array}$ \\
\hline & & & & & & $\begin{array}{l}\text { Gabapentin } \\
600 \mathrm{mg}\end{array}$ & 40 & \\
\hline & $\begin{array}{l}\text { Khezri } \\
\text { 2013a [37] }\end{array}$ & $\begin{array}{l}\text { ASA IV patients aged } \\
35 \text { to } 85\end{array}$ & $\begin{array}{l}\text { Cataract surgery under } \\
\text { retrobulbar nerve block }\end{array}$ & Melatonin $6 \mathrm{mg}$ & 40 & Placebo & 40 & $\begin{array}{l}\text { Sublingual premedication } \\
90 \text { min before arrival in the } \\
\text { operating room }\end{array}$ \\
\hline & $\begin{array}{l}\text { Borazan } \\
2010[41]\end{array}$ & $\begin{array}{l}\text { ASA I-II patients aged } \\
50 \text { to } 65\end{array}$ & $\begin{array}{l}\text { Elective open prostatectomy } \\
\text { under general anesthesia }\end{array}$ & Melatonin $6 \mathrm{mg}$ & 26 & Placebo & 26 & $\begin{array}{l}\text { Oral premedication at the } \\
\text { night before and } 1 \mathrm{~h} \text { before } \\
\text { surgery }\end{array}$ \\
\hline & $\begin{array}{l}\text { Ismail } \\
2009[42]\end{array}$ & $\begin{array}{l}\text { ASA I-III patients } \\
\text { older than } 60 \text { years }\end{array}$ & $\begin{array}{l}\text { Cataract surgery with } \\
\text { intraocular lens implantation } \\
\text { under topical anesthesia }\end{array}$ & Melatonin $10 \mathrm{mg}$ & 20 & Placebo & 20 & $\begin{array}{l}\text { Oral premedication } \\
90 \text { min before surgery }\end{array}$ \\
\hline & $\begin{array}{l}\text { Caumo } \\
2009[44]\end{array}$ & $\begin{array}{l}\text { ASA I-II patients } \\
\text { aged } 19 \text { to } 60\end{array}$ & $\begin{array}{l}\text { Abdominal hysterectomy for } \\
\text { myomatosis under regional } \\
\text { anesthesia }\end{array}$ & Melatonin $5 \mathrm{mg}$ & 20 & Placebo & 20 & $\begin{array}{l}\text { Oral premedication the } \\
\text { night before and } 1 \text { hour before } \\
\text { surgery }\end{array}$ \\
\hline & & & & & & Clonidine $100 \mathrm{mg}$ & 19 & \\
\hline & $\begin{array}{l}\text { Caumo } \\
2007[45]\end{array}$ & $\begin{array}{l}\text { ASA I-II aged } 30 \\
\text { to } 55\end{array}$ & $\begin{array}{l}\text { Abdominal hysterectomy } \\
\text { under regional anesthesia }\end{array}$ & Melatonin $5 \mathrm{mg}$ & 17 & Placebo & 16 & $\begin{array}{l}\text { Oral premedication at the } \\
\text { night before and } 1 \mathrm{~h} \text { before } \\
\text { surgery }\end{array}$ \\
\hline \multirow[t]{7}{*}{$\begin{array}{l}\text { Inflammatory } \\
\text { pain }\end{array}$} & $\begin{array}{l}\text { de Zanette } \\
2014 \text { [34] }\end{array}$ & Females aged 18 to 65 & Fibromyalgia & $\begin{array}{l}\text { Melatonin } 10 \mathrm{mg} \text { and } \\
\text { amitriptyline } 25 \mathrm{mg}\end{array}$ & 21 & Amitriptyline $25 \mathrm{mg}$ & 21 & $\begin{array}{l}\text { Oral premedication } \\
\text { at bedtime for } 6 \text { weeks }\end{array}$ \\
\hline & & & & Melatonin $10 \mathrm{mg}$ & 21 & & & \\
\hline & $\begin{array}{l}\text { Vidor } 2013 \\
{[68]}\end{array}$ & Females aged 20 to 40 & $\begin{array}{l}\text { Myofascial } \\
\text { temporomandibular disorder }\end{array}$ & Melatonin $5 \mathrm{mg}$ & 16 & Placebo & 15 & $\begin{array}{l}\text { Oral premedication } \\
\text { at bedtime for } 4 \text { weeks }\end{array}$ \\
\hline & $\begin{array}{l}\text { Schwertner } \\
2013[38]\end{array}$ & $\begin{array}{l}\text { Female patients aged } \\
18 \text { to } 45\end{array}$ & $\begin{array}{l}\text { Endometriosis-associated } \\
\text { chronic pelvic pain }\end{array}$ & Melatonin $10 \mathrm{mg}$ & 20 & Placebo & 20 & $\begin{array}{l}\text { Oral premedication } \\
\text { at bedtime for } 8 \text { weeks }\end{array}$ \\
\hline & $\begin{array}{l}\text { Hussain } \\
2011[40]\end{array}$ & $\begin{array}{l}\text { Patients with primary } \\
\text { fibromyalgia aged } \\
18-65\end{array}$ & Fibromyalgia syndrome & $\begin{array}{l}\text { Melatonin } 5 \mathrm{mg} \text { and } \\
\text { placebo }\end{array}$ & 27 & $\begin{array}{l}\text { Fluoxetine } 20 \mathrm{mg} \text { and } \\
\text { placebo }\end{array}$ & 24 & $\begin{array}{l}\text { Oral premedication of melatonin } \\
\text { as single daily dose at night time, } \\
\text { and fluoxetine as single daily } \\
\text { dose in the morning for } 60 \text { days. }\end{array}$ \\
\hline & & & & $\begin{array}{l}\text { Melatonin } 5 \mathrm{mg} \text { and } \\
\text { fluoxetine } 20 \mathrm{mg}\end{array}$ & 23 & & & \\
\hline & $\begin{array}{l}\text { Song } 2005 \\
{[57]}\end{array}$ & $\begin{array}{l}\text { Irritable bowel } \\
\text { syndrome patients } \\
\text { with sleep } \\
\text { disturbances,aged } \\
20 \text { to } 64\end{array}$ & $\begin{array}{l}\text { Abdominal pain induced by } \\
\text { irritable bowel syndroms }\end{array}$ & Melatonin $3 \mathrm{mg}$ & 20 & Placebo & 20 & $\begin{array}{l}\text { Oral premedication at } \\
\text { bedtime for } 2 \text { weeks }\end{array}$ \\
\hline \multirow[t]{3}{*}{$\begin{array}{l}\text { Procedural } \\
\text { pain }\end{array}$} & $\begin{array}{l}\text { Marseglia } \\
2015[67]\end{array}$ & Children aged 1 to 14 & $\begin{array}{l}\text { Pain undergoing blood } \\
\text { withdrawal }\end{array}$ & $\begin{array}{l}\text { Melatonin } 0.5 \mathrm{mg} / \mathrm{kg} \\
(\max 5 \mathrm{mg})\end{array}$ & 30 & Placebo & 30 & $\begin{array}{l}\text { Oral premedication } \\
30 \text { min before blood drawing }\end{array}$ \\
\hline & $\begin{array}{l}\text { Gitto } 2012 \\
{[39]}\end{array}$ & $\begin{array}{l}\text { Newborns of } 32 \\
\text { weeks gestation } \\
\text { or less }\end{array}$ & Endotracheal intubation & $\begin{array}{l}\text { Melatonin } 10 \\
\mathrm{mg} / \mathrm{kg} \text {, standard } \\
\text { pharmacological and } \\
\text { nonpharmacological } \\
\text { therapy }\end{array}$ & 30 & $\begin{array}{l}\text { Standard } \\
\text { pharmacological } \\
\text { and } \\
\text { nonpharmacological } \\
\text { therapy }\end{array}$ & 30 & $\begin{array}{l}\text { Intravenously before } \\
\text { endotracheal intubation }\end{array}$ \\
\hline & $\begin{array}{l}\text { Mowafi } \\
2008[43]\end{array}$ & ASA I-II patients & $\begin{array}{l}\text { Pain after intravenous } \\
\text { cannula were placed under } \\
\text { tourniquet }\end{array}$ & Melatonin $10 \mathrm{mg}$ & 20 & Placebo & 20 & $\begin{array}{l}\text { Oral premedication } \\
90 \text { min before surgery }\end{array}$ \\
\hline \multirow[t]{5}{*}{$\begin{array}{l}\text { Experimental } \\
\text { pain }\end{array}$} & $\begin{array}{l}\text { Andersen } \\
2015[30]\end{array}$ & $\begin{array}{l}\text { Healthy male } \\
\text { volunteers aged } 20 \\
\text { to } 40\end{array}$ & Validated burn injury & Melatonin $10 \mathrm{mg}$ & 29 & Placebo & 29 & $\begin{array}{l}\text { Intravenous } \\
\text { administration } \\
60 \text { min before test }\end{array}$ \\
\hline & & & & Melatonin $100 \mathrm{mg}$ & 29 & & & \\
\hline & $\begin{array}{l}\text { Stefani } \\
2013[36]\end{array}$ & $\begin{array}{l}\text { White healthy } \\
\text { volunteers aged } 19 \\
\text { to } 47\end{array}$ & Pressure and heat pain & $\begin{array}{l}\text { Melatonin } 0.05 \\
\mathrm{mg} / \mathrm{kg}\end{array}$ & 15 & placebo & 15 & $\begin{array}{l}\text { Sublingual premedication } \\
30 \text { min before test }\end{array}$ \\
\hline & & & & $\begin{array}{l}\text { Melatonin } 0.15 \\
\mathrm{mg} / \mathrm{kg}\end{array}$ & 15 & & & \\
\hline & & & & $\begin{array}{l}\text { Melatonin } 0.25 \\
\mathrm{mg} / \mathrm{kg}\end{array}$ & 16 & & & \\
\hline
\end{tabular}


syndrome and elevates morning melatonin levels [56]. In particular, the increased morning melatonin levels were correlated with improved bowel habits and irritable bowel syndrome-associated pain (with a regression coefficient of $0.61)$ [56]. This study is coincident with the observation that direct supplement of melatonin also improved irritable bowel syndrome-associated visceral pain [54, 57].

Melatonin is involved in the physiopathology of pain. BDNF is an important mediator and a central modulator of pain [58-60]. In neuropathic pain, BDNF release has been observed in the spinal cord, contributing to chronic pain [61]. Further study found that BDNF contributed to hyperpathia through presynaptic GABAergic inhibition [62]. In the colonic mucosa of patients with irritable bowel syndrome, increased BDNF expression was correlated with visceral hyperalgesia and increased abdominal pain scores [63]. The mechanisms for these observations may be involved in elevating tyrosine receptor kinase $\mathrm{B}$ expression [63]. BDNF is an important regulator of pain, and the antinociceptive mechanisms of melatonin may be attributed to decreased BDNF levels [34]. Furthermore, production of inflammatory factors is important to induce and maintain pain [64]. Melatonin can also reduce inflammatory cytokine levels, including interleukin (IL)-6, IL-8, IL10 and IL-12, in newborns undergoing intubation and mechanical ventilation [39]. Another experimental animal study showed that melatonin significantly attenuated inflammation-mediated hyperalgesia in rats [65].

The analgesic effects of melatonin may also be influenced by several factors, such as the duration of administration and gender. In an experimental animal study with Freund's adjuvant-induced inflammatory pain, the different administration durations of melatonin differently influenced the BDNF levels [66]. To be specific, short-term (3 days), but not long-term (8 days) administration of melatonin increased BDNF levels [66]. The analgesic effects of melatonin may be better in females than in males [47]. Seet et al. [47] found insignificant effects of melatonin in patients undergoing elective extraction of all four wisdom teeth, while further subgroup analysis showed a positive effect of melatonin in female, but not male, patients. Sexual dimorphism has also been indicated in other studies [56]. Elevated melatonin levels due to probiotics are observed in male patients, but not in female patients, further alleviating pain. In particular, the anti-nociceptive effects of melatonin in the pediatric population have been explored. However, further confirmation regarding melatonin application in this population is needed from more clinical trials.

In this meta-analysis, we conducted a systematic search for melatonin administration on anti-nociception. The pooling data included all available RCTs, involving 1053 patients. Strong evidence supports the utilization of melatonin on anti-nociception against many types of pain. Several limitations need to be considered. First, profound heterogeneity of the secondary outcome was found, i.e., total analgesic consumption. Although further subgroup analyses were performed to identify the heterogeneity source, no potential methodological and clinical sources of heterogeneity were identified. The considerable heterogeneity was also unaffected by exclusion of individual RCTs. Thus, a random-effects model was used for these data. Furthermore, the magnitude of this outcome

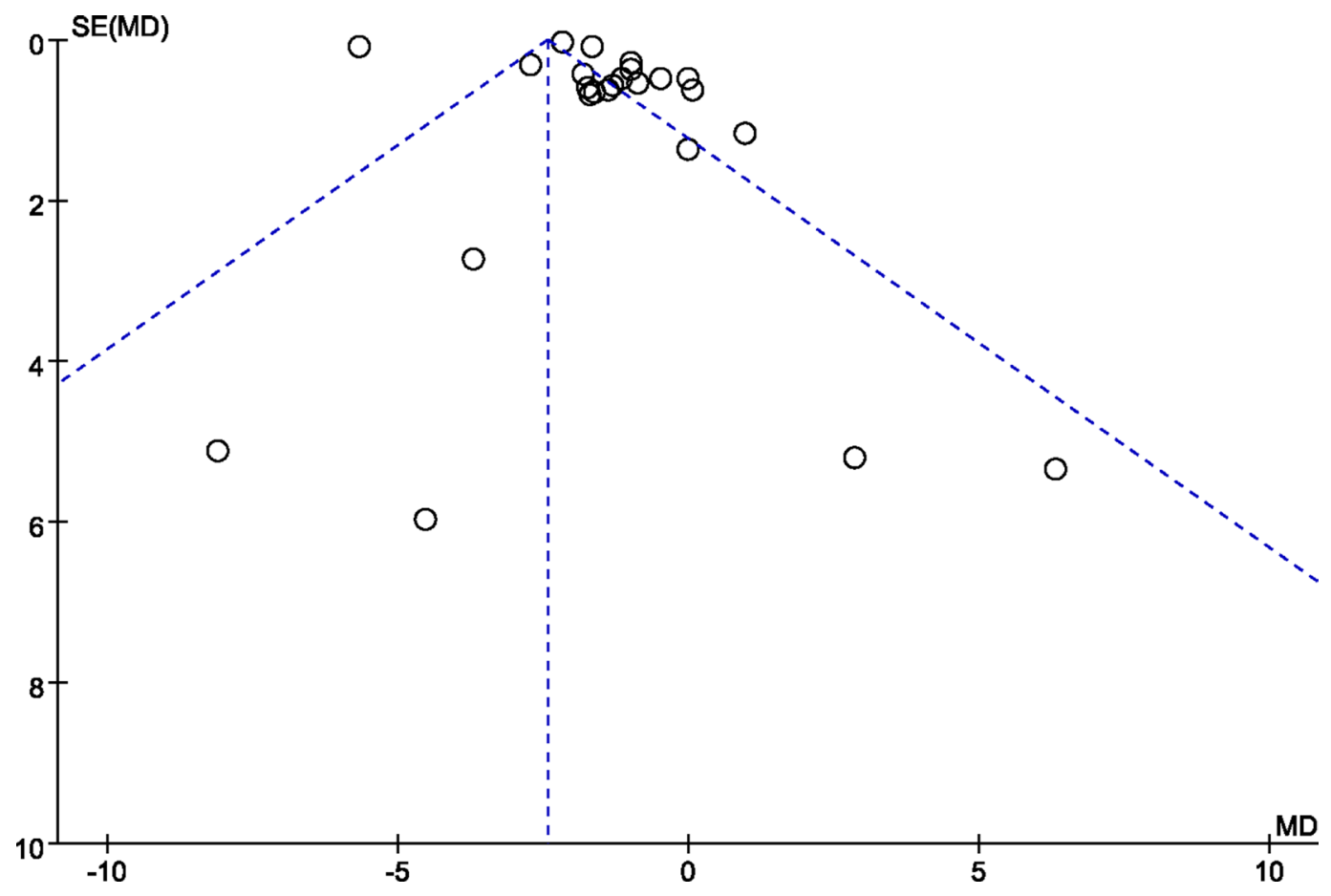

Figure 2: Funnel plot of comparison: pain score. Eggers test: $1.121428,95 \%$ CI: -3.588125 to $5.830981, P=0.623$. 


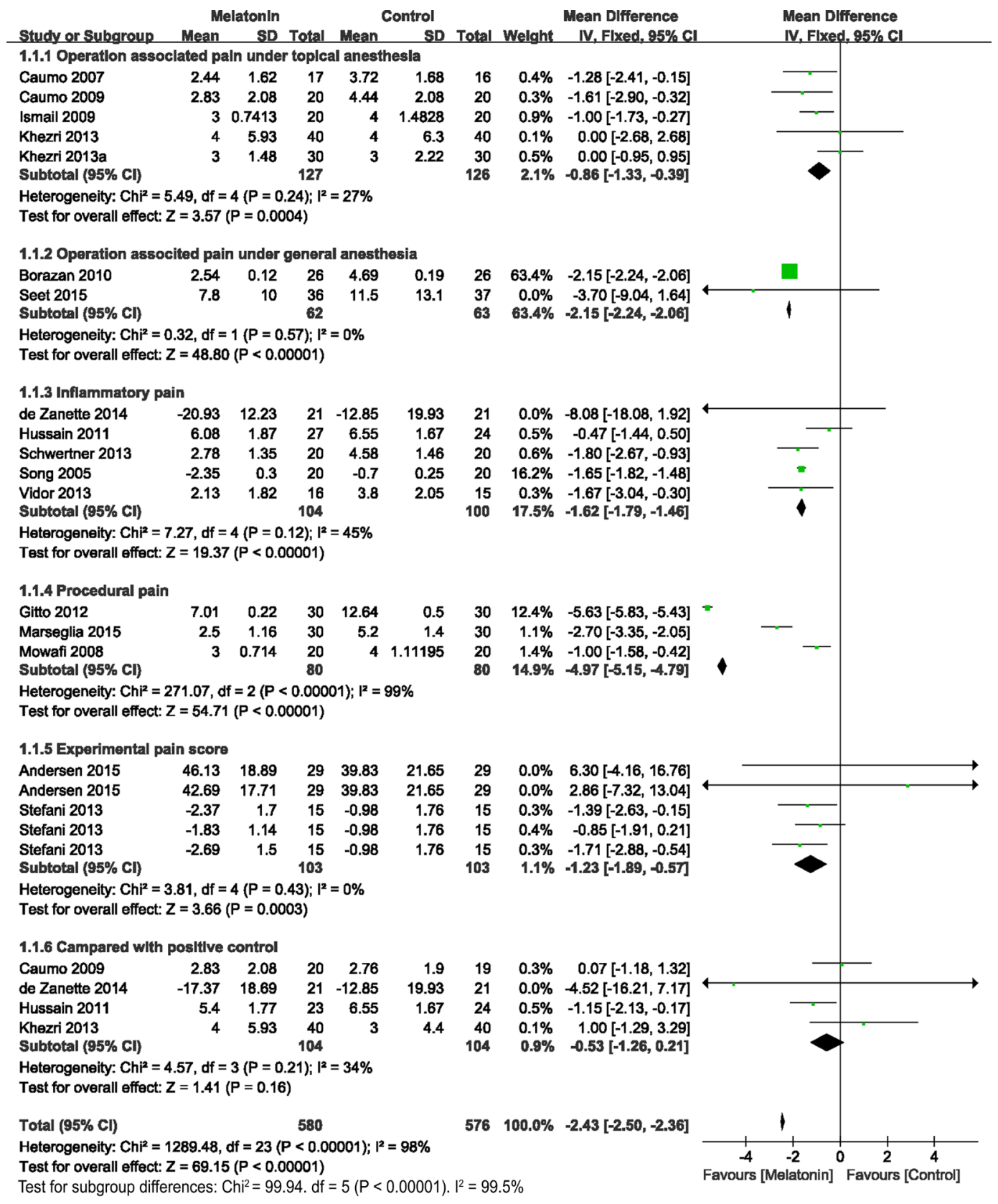

Figure 3: Forest plot: pain intensity indicated by the pain score.

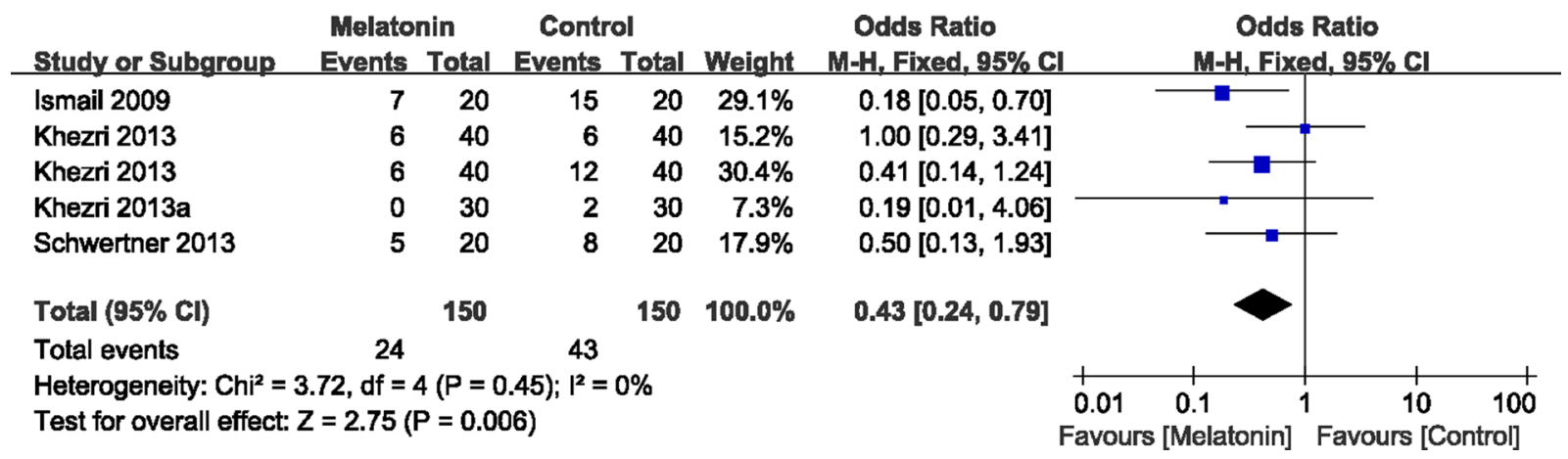

Figure 4: Forest plot: proportion of patients with analgesic requirements. 


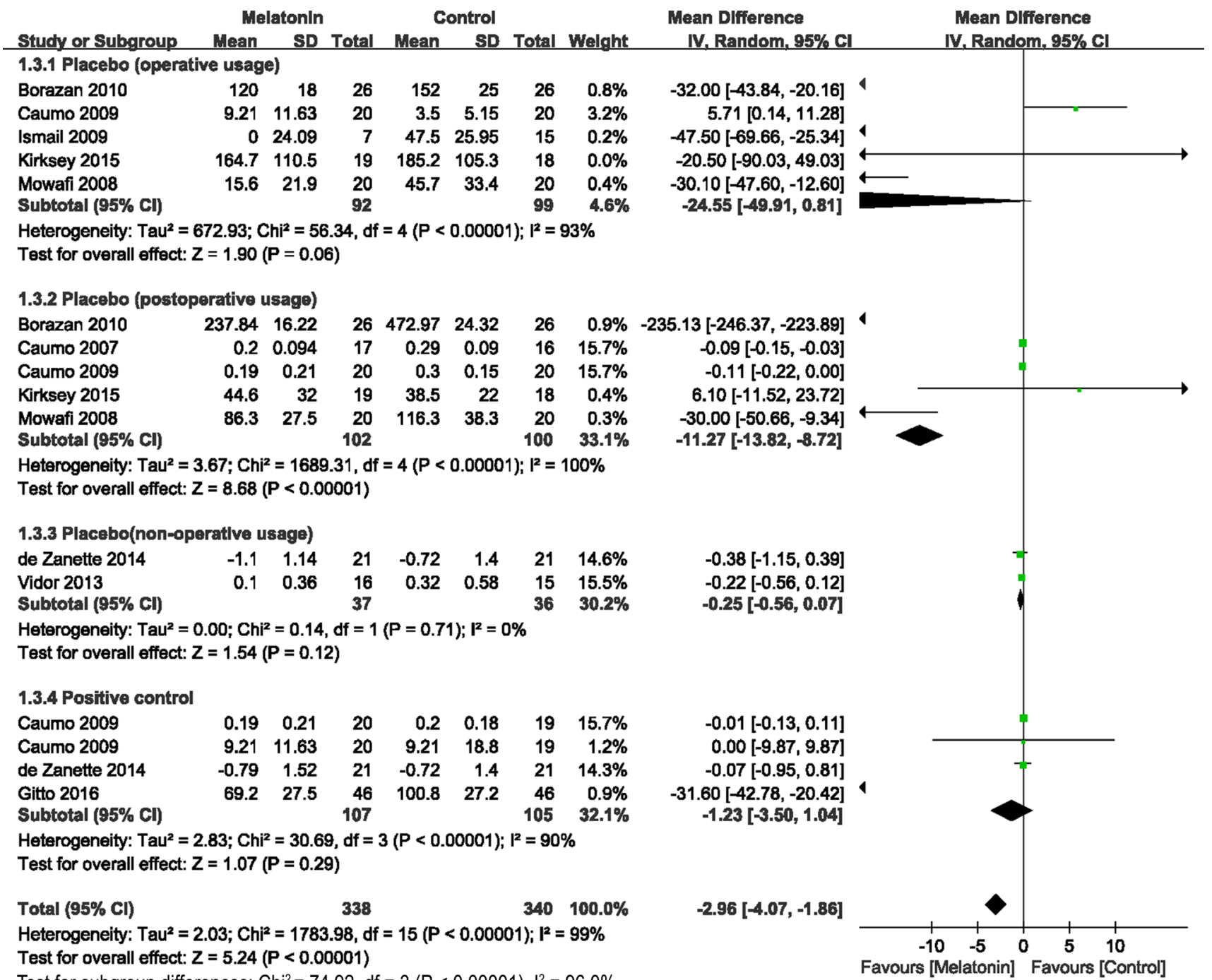

Figure 5: Forest plot: total analgesic consumption.

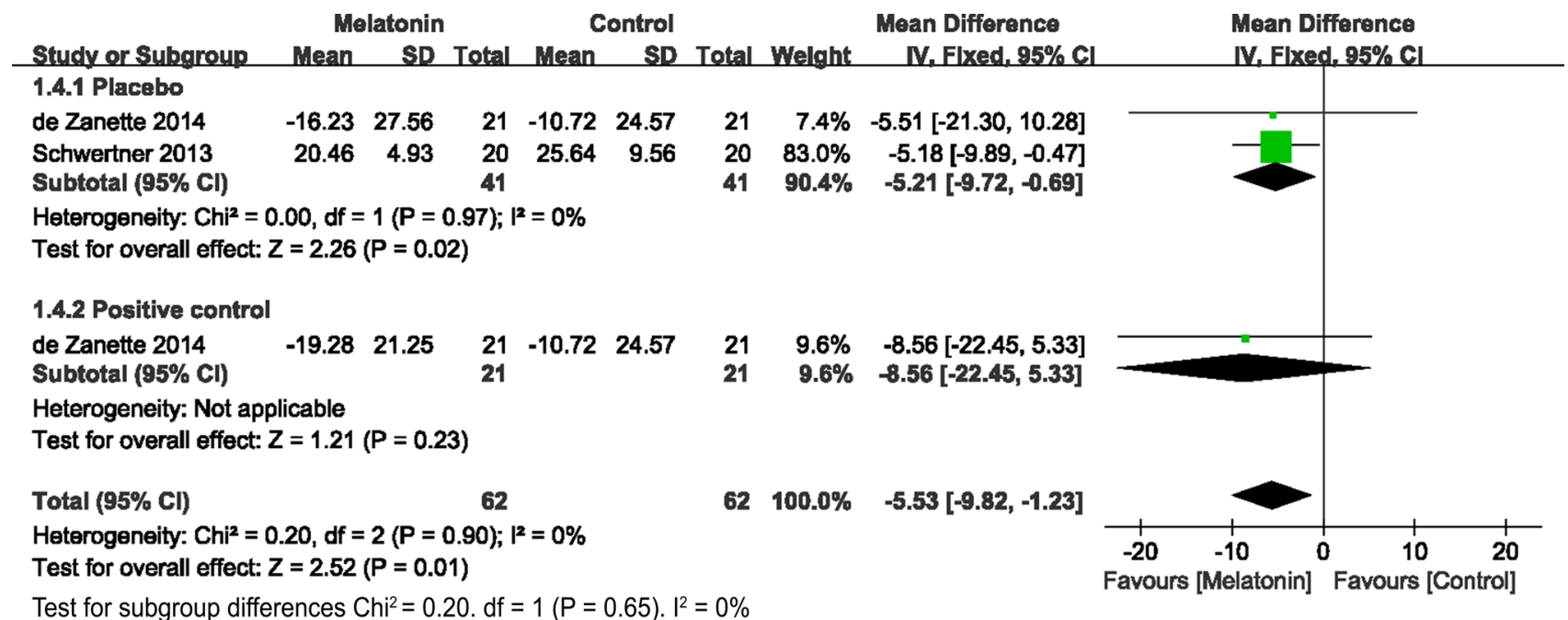

Figure 6: Forest plot: BDNF levels. BDNF, brain-derived neurotrophic factor. 
was influenced by some studies. Second, although the data analysis demonstrated that melatonin significantly reduced the proportion of patients with analgesic requirements and decreased BDNF levels, these results may need support from more studies. Third, several influencing factors, such as duration of administration and sexual dimorphism in melatonin's analgesic effects, have been indicated; however, these observations were limited by the original design of the clinical trials and need to be further validated in well-designed studies.

\section{CONFLICTS OF INTEREST}

None.

\section{FUNDING}

This work was supported by the National Natural Science Fund of China (81171637) and the Basic Science Research Project of Shaanxi Province (2014JM4186).

\section{REFERENCES}

1. Garcia JJ, Lopez-Pingarron L, Almeida-Souza P, Tres A, Escudero P, Garcia-Gil FA, Tan DX, Reiter RJ, Ramirez JM, Bernal-Perez M. Protective effects of melatonin in reducing oxidative stress and in preserving the fluidity of biological membranes: a review. J Pineal Res. 2014; 56:225-237.

2. Manchester LC, Coto-Montes A, Boga JA, Andersen LP, Zhou Z, Galano A, Vriend J, Tan DX, Reiter RJ. Melatonin: an ancient molecule that makes oxygen metabolically tolerable. J Pineal Res. 2015; 59:403-419.

3. Zhang HM, Zhang Y. Melatonin: a well-documented antioxidant with conditional pro-oxidant actions. J Pineal Res. 2014; 57:131-146.

4. Borges Lda S, Dermargos A, da Silva Junior EP, Weimann E, Lambertucci RH, Hatanaka E. Melatonin decreases muscular oxidative stress and inflammation induced by strenuous exercise and stimulates growth factor synthesis. J Pineal Res. 2015; 58:166-172.

5. Jin H, Wang Y, Zhou L, Liu L, Zhang P, Deng W, Yuan Y. Melatonin attenuates hypoxic pulmonary hypertension by inhibiting the inflammation and the proliferation of pulmonary arterial smooth muscle cells. J Pineal Res. 2014; $57: 442-450$

6. Cano Barquilla P, Pagano ES, Jimenez-Ortega V, FernandezMateos P, Esquifino AI, Cardinali DP. Melatonin normalizes clinical and biochemical parameters of mild inflammation in diet-induced metabolic syndrome in rats. J Pineal Res. 2014; 57:280-290.

7. Chen J, Chen G, Li J, Qian C, Mo H, Gu C, Yan F, Yan W, Wang L. Melatonin attenuates inflammatory response-induced brain edema in early brain injury following a subarachnoid hemorrhage: a possible role for the regulation of proinflammatory cytokines. J Pineal Res. 2014; 57:340-347.
8. Reiter RJ, Mayo JC, Tan DX, Sainz RM, Alatorre-Jimenez M, Qin L. Melatonin as an antioxidant: under promises but over delivers. J Pineal Res. 2016; 61:253-278.

9. Vriend J, Reiter RJ. Melatonin feedback on clock genes: a theory involving the proteasome. J Pineal Res. 2015; 58:1-11.

10. Cardinali DP, Furio AM, Reyes MP. Clinical perspectives for the use of melatonin as a chronobiotic and cytoprotective agent. Ann N Y Acad Sci. 2005; 1057:327-336.

11. Hu W, Ma Z, Di S, Jiang S, Li Y, Fan C, Yang Y, Wang D. Snapshot: implications for melatonin in endoplasmic reticulum homeostasis. Br J Pharmacol. 2016; 173:3431-3442.

12. Hu W, Ma Z, Jiang S, Fan C, Deng C, Yan X, Di S, Lv J, Reiter RJ, Yang Y. Melatonin: the dawning of a treatment for fibrosis? J Pineal Res. 2016; 60:121-131.

13. Hu W, Deng C, Ma Z, Wang D, Fan C, Li T, Di S, Gong B, Reiter RJ, Yang Y. Utilizing melatonin to combat bacterial infections and septic injury. Br J Pharmacol. 2017; 174:754-768.

14. Peschke E, Bahr I, Muhlbauer E. Experimental and clinical aspects of melatonin and clock genes in diabetes. J Pineal Res. 2015; 59:1-23.

15. Szewczyk-Golec K, Wozniak A, Reiter RJ. Interrelationships of the chronobiotic, melatonin, with leptin and adiponectin: implications for obesity. J Pineal Res. 2015; 59:277-291.

16. Hansen MV, Andersen LT, Madsen MT, Hageman I, Rasmussen LS, Bokmand S, Rosenberg J, Gogenur I. Effect of melatonin on depressive symptoms and anxiety in patients undergoing breast cancer surgery: a randomized, double-blind, placebo-controlled trial. Breast Cancer Res Treat. 2014; 145:683-695.

17. Jorgensen KM, Witting MD. Does exogenous melatonin improve day sleep or night alertness in emergency physicians working night shifts? Ann Emerg Med. 1998; 31:699-704.

18. Gogenur I, Kucukakin B, Bisgaard T, Kristiansen V, Hjortso NC, Skene DJ, Rosenberg J. The effect of melatonin on sleep quality after laparoscopic cholecystectomy: a randomized, placebo-controlled trial. Anesth Analg. 2009; 108:1152-1156.

19. Lin TB, Hsieh MC, Lai CY, Cheng JK, Wang HH, Chau YP, Chen GD, Peng HY. Melatonin relieves neuropathic allodynia through spinal MT2-enhanced PP2Ac and downstream HDAC4 shuttling-dependent epigenetic modification of hmgbl transcription. J Pineal Res. 2016; 60:263-276.

20. Zahn PK, Lansmann T, Berger E, Speckmann EJ, Musshoff U. Gene expression and functional characterization of melatonin receptors in the spinal cord of the rat: implications for pain modulation. J Pineal Res. 2003; 35:24-31.

21. Aviram J, Shochat T, Pud D. Pain perception in healthy young men is modified by time-of-day and is modality dependent. Pain Med. 2015; 16:1137-1144. 
22. Nelson FA, Farr LA, Ebadi M. Salivary melatonin response to acute pain stimuli. J Pineal Res. 2001; 30:206-212.

23. Chiang RP, Huang CT, Tsai YJ. Melatonin reduces median nerve injury-induced mechanical hypersensitivity via inhibition of microglial p38 mitogen-activated protein kinase activation in rat cuneate nucleus. J Pineal Res. 2013; 54:232-244.

24. Huang CT, Chiang RP, Chen CL, Tsai YJ. Sleep deprivation aggravates median nerve injury-induced neuropathic pain and enhances microglial activation by suppressing melatonin secretion. Sleep. 2014; 37:1513-1523.

25. Areti A, Komirishetty P, Akuthota M, Malik RA, Kumar A. Melatonin prevents mitochondrial dysfunction and promotes neuroprotection by inducing autophagy during oxaliplatinevoked peripheral neuropathy. J Pineal Res. 2017; 62.

26. Agorastos A, Linthorst AC. Potential pleiotropic beneficial effects of adjuvant melatonergic treatment in posttraumatic stress disorder. J Pineal Res. 2016; 61:3-26.

27. Wilhelmsen M, Amirian I, Reiter RJ, Rosenberg J, Gogenur I. Analgesic effects of melatonin: a review of current evidence from experimental and clinical studies. J Pineal Res. 2011; 51:270-277.

28. Dominguez-Rodriguez A, Abreu-Gonzalez P, de la TorreHernandez JM, Gonzalez-Gonzalez J, Garcia-Camarero T, Consuegra-Sanchez L, Garcia-Saiz MD, Aldea-Perona A, Virgos-Aller T, Azpeitia A, Reiter RJ. Effect of intravenous and intracoronary melatonin as an adjunct to primary percutaneous coronary intervention for acute ST-elevation myocardial infarction: Results of the Melatonin Adjunct in the acute myocaRdial Infarction treated with Angioplasty trial. J Pineal Res. 2017; 62.

29. Andersen LP, Werner MU, Rosenkilde MM, Fenger AQ, Petersen MC, Rosenberg J, Gogenur I. Pharmacokinetics of high-dose intravenous melatonin in humans. J Clin Pharmacol. 2016; 56:324-329.

30. Andersen LP, Gogenur I, Fenger AQ, Petersen MC, Rosenberg J, Werner MU. Analgesic and antihyperalgesic effects of melatonin in a human inflammatory pain model: a randomized, double-blind, placebo-controlled, three-arm crossover study. Pain. 2015; 156:2286-2294.

31. Fallah R, Yadegari Y, Behdad S, Akhavan Karbasi S. Melatonin and intravenous midazolam administered orally in drug induced sleep electroencephalography of children: randomized clinical trial of efficacy. Arch Iran Med. 2014; 17:741-745.

32. Andersen LP, Kucukakin B, Werner MU, Rosenberg J, Gogenur I. Absence of analgesic effect of intravenous melatonin administration during daytime after laparoscopic cholecystectomy: a randomized trial. J Clin Anesth. 2014; 26:545-550.

33. Gitto E, Marseglia L, D'Angelo G, Manti S, Crisafi C, Montalto AS, Impellizzeri P, Reiter RJ, Romeo C. Melatonin versus midazolam premedication in children undergoing surgery: A pilot study. J Paediatr Child Health. 2016; 52:291-295.
34. de Zanette SA, Vercelino R, Laste G, Rozisky JR, Schwertner A, Machado CB, Xavier F, de Souza IC, Deitos A, Torres IL, Caumo W. Melatonin analgesia is associated with improvement of the descending endogenous painmodulating system in fibromyalgia: a phase II, randomized, double-dummy, controlled trial. BMC Pharmacol Toxicol. 2014; 15:40.

35. Khezri MB, Oladi MR, Atlasbaf A. Effect of melatonin and gabapentin on anxiety and pain associated with retrobulbar eye block for cataract surgery: a randomized double-blind study. Indian J Pharmacol. 2013; 45:581-586.

36. Stefani LC, Muller S, Torres IL, Razzolini B, Rozisky JR, Fregni F, Markus R, Caumo W. A Phase II, Randomized, Double-Blind, Placebo Controlled, Dose-Response Trial of the Melatonin Effect on the Pain Threshold of Healthy Subjects. PLoS One. 2013; 8:e74107.

37. Khezri MB, Merate H. The effects of melatonin on anxiety and pain scores of patients, intraocular pressure, and operating conditions during cataract surgery under topical anesthesia. Indian J Ophthalmol. 2013; 61:319-324.

38. Schwertner A, Conceicao Dos Santos CC, Costa GD, Deitos A, de Souza A, de Souza IC, Torres IL, da Cunha Filho JS, Caumo W. Efficacy of melatonin in the treatment of endometriosis: a phase II, randomized, double-blind, placebo-controlled trial. Pain. 2013; 154:874-881.

39. Gitto E, Aversa S, Salpietro CD, Barberi I, Arrigo T, Trimarchi G, Reiter RJ, Pellegrino S. Pain in neonatal intensive care: role of melatonin as an analgesic antioxidant. J Pineal Res. 2012; 52:291-295.

40. Hussain SA, Al-Khalifa II, Jasim NA, Gorial FI. Adjuvant use of melatonin for treatment of fibromyalgia. J Pineal Res. 2011; 50:267-271.

41. Borazan H, Tuncer S, Yalcin N, Erol A, Otelcioglu S. Effects of preoperative oral melatonin medication on postoperative analgesia, sleep quality, and sedation in patients undergoing elective prostatectomy: a randomized clinical trial. J Anesth. 2010; 24:155-160.

42. Ismail SA, Mowafi HA. Melatonin provides anxiolysis, enhances analgesia, decreases intraocular pressure, and promotes better operating conditions during cataract surgery under topical anesthesia. Anesth Analg. 2009; 108:11461151.

43. Mowafi HA, Ismail SA. Melatonin improves tourniquet tolerance and enhances postoperative analgesia in patients receiving intravenous regional anesthesia. Anesth Analg. 2008; 107:1422-1426.

44. Caumo W, Levandovski R, Hidalgo MP. Preoperative anxiolytic effect of melatonin and clonidine on postoperative pain and morphine consumption in patients undergoing abdominal hysterectomy: a double-blind, randomized, placebo-controlled study. J Pain. 2009; 10:100-108.

45. Caumo W, Torres F, Moreira NL Jr, Auzani JA, Monteiro CA, Londero G, Ribeiro DF, Hidalgo MP. The clinical impact of preoperative melatonin on postoperative 
outcomes in patients undergoing abdominal hysterectomy. Anesth Analg. 2007; 105:1263-1271, table of contents.

46. Kirksey MA, Yoo D, Danninger T, Stundner O, Ma Y, Memtsoudis SG. Impact of Melatonin on Sleep and Pain After Total Knee Arthroplasty Under Regional Anesthesia With Sedation: A Double-Blind, Randomized, PlaceboControlled Pilot Study. J Arthroplasty. 2015; 30:2370-2375.

47. Seet E, Liaw CM, Tay S, Su C. Melatonin premedication versus placebo in wisdom teeth extraction: a randomised controlled trial. Singapore Med J. 2015; 56:666-671.

48. Higgins JPT, Green S, eds. Cochrane Handbook for Systematic Reviews of Interventions Version 502 [updated September 2009]. The Cochrane Collaboration. 2009.

49. Jadad AR, Moore RA, Carroll D, Jenkinson C, Reynolds DJ, Gavaghan DJ, McQuay HJ. Assessing the quality of reports of randomized clinical trials: is blinding necessary? Control Clin Trials. 1996; 17:1-12.

50. Begg CB, Mazumdar M. Operating characteristics of a rank correlation test for publication bias. Biometrics. 1994; 50:1088-1101.

51. Egger M, Davey Smith G, Schneider M, Minder C. Bias in meta-analysis detected by a simple, graphical test. BMJ. 1997; 315:629-634.

52. Mistraletti G, Umbrello M, Sabbatini G, Miori S, Taverna M, Cerri B, Mantovani ES, Formenti P, Spanu P, D'Agostino A, Salini S, Morabito A, Fraschini F, et al. Melatonin reduces the need for sedation in ICU patients: a randomized controlled trial. Minerva Anestesiol. 2015; 81:1298-1310.

53. Klupinska G, Poplawski T, Drzewoski J, Harasiuk A, Reiter RJ, Blasiak J, Chojnacki J. Therapeutic effect of melatonin in patients with functional dyspepsia. J Clin Gastroenterol. 2007; 41:270-274.

54. Chojnacki C, Walecka-Kapica E, Lokiec K, Pawlowicz M, Winczyk K, Chojnacki J, Klupinska G. Influence of melatonin on symptoms of irritable bowel syndrome in postmenopausal women. Endokrynol Pol. 2013; 64:114-120.

55. Mistraletti G, Mantovani ES, Cadringher P, Cerri B, Corbella D, Umbrello M, Anania S, Andrighi E, Barello S, Di Carlo A, Martinetti F, Formenti P, Spanu P, Iapichino G. Enteral vs. intravenous ICU sedation management: study protocol for a randomized controlled trial. Trials. 2013; 14:92.

56. Wong RK, Yang C, Song GH, Wong J, Ho KY. Melatonin regulation as a possible mechanism for probiotic (VSL\#3) in irritable bowel syndrome: a randomized double-blinded placebo study. Dig Dis Sci. 2015; 60:186-194.

57. Song GH, Leng PH, Gwee KA, Moochhala SM, Ho KY. Melatonin improves abdominal pain in irritable bowel syndrome patients who have sleep disturbances: a randomised, double blind, placebo controlled study. Gut. 2005; 54:1402-1407.

58. Pezet S, McMahon SB. Neurotrophins: mediators and modulators of pain. Annu Rev Neurosci. 2006; 29:507-538.

59. Ren K, Dubner R. Pain facilitation and activity-dependent plasticity in pain modulatory circuitry: role of BDNF-TrkB signaling and NMDA receptors. Mol Neurobiol. 2007; 35:224-235.

60. Guo W, Robbins MT, Wei F, Zou S, Dubner R, Ren K. Supraspinal brain-derived neurotrophic factor signaling: a novel mechanism for descending pain facilitation. J Neurosci. 2006; 26:126-137.

61. Ulmann L, Hatcher JP, Hughes JP, Chaumont S, Green PJ, Conquet F, Buell GN, Reeve AJ, Chessell IP, Rassendren F. Up-regulation of $\mathrm{P} 2 \mathrm{X} 4$ receptors in spinal microglia after peripheral nerve injury mediates BDNF release and neuropathic pain. J Neurosci. 2008; 28:11263-11268.

62. Chen JT, Guo D, Campanelli D, Frattini F, Mayer F, Zhou L, Kuner R, Heppenstall PA, Knipper M, Hu J. Presynaptic GABAergic inhibition regulated by BDNF contributes to neuropathic pain induction. Nat Commun. 2014; 5:5331.

63. Yu YB, Zuo XL, Zhao QJ, Chen FX, Yang J, Dong YY, Wang P, Li YQ. Brain-derived neurotrophic factor contributes to abdominal pain in irritable bowel syndrome. Gut. 2012; 61:685-694.

64. Ji RR, $\mathrm{Xu} \mathrm{ZZ}$, Gao YJ. Emerging targets in neuroinflammation-driven chronic pain. Nat Rev Drug Discov. 2014; 13:533-548.

65. Esposito E, Paterniti I, Mazzon E, Bramanti P, Cuzzocrea S. Melatonin reduces hyperalgesia associated with inflammation. J Pineal Res. 2010; 49:321-331.

66. Laste G, Ripoll Rozisky J, Caumo W, Lucena da Silva Torres I. Short- but not long-term melatonin administration reduces central levels of brain-derived neurotrophic factor in rats with inflammatory pain. Neuroimmunomodulation. 2015; 22:358-364.

67. Marseglia L, Manti S, D'Angelo G, Arrigo T, Cuppari C, Salpietro C, Gitto E. Potential Use of Melatonin in Procedural Anxiety and Pain in Children Undergoing Blood Withdrawal. J Biol Regul Homeost Agents. 2015; 29:509514.

68. Vidor LP, Torres IL, Custodio de Souza IC, Fregni F, Caumo W. Analgesic and sedative effects of melatonin in temporomandibular disorders: a double-blind, randomized, parallel-group, placebo-controlled study. J Pain Symptom Manage. 2013; 46:422-432. 